\title{
Влияние фитоминералсорбентов на гнойный раневой процесс
}

\author{
Круть У.А., Везенцев А.И., Кузубова Е.В., \\ Радченко А.И., Шайдорова Г.М.
}

Белгородский государственный национальный исследовательский университет, Белгород

Поступила в редакцию 18.10.2018 г.

DOI: https://doi.org/10.17308/sorpchrom.2018.18/621

Приведены результаты исследования фитоминералсорбентов. Исследовано влияние модифицированной монтмориллонит содержащей глины на ранозаживление у лабораторных крыс линии Вистар. Была исследована клиническая картина крови крыс после нанесения модельной раны. В ходе проведенной работы было изучено изменение площади раневого дефекта при моделировании гнойной раны у крыс в эксперименте

Ключевые слова: фитоминералсорбент, гнойные раны, гемосорбция, морфологический анализ крови крыс.

\section{The influence of vitamineral sorbents on the purulent wound process}

\author{
Krut U.A., Vezentsev A.I., Kuzubova E.V., \\ Radchenko A.I., Shaydorova G.M. \\ Belgorod State University, Belgorod
}

The purpose of this study is to determine the effect of modified montmorillonite clays on the wound-healing process of purulent wounds of laboratory rats. The results of the study of phyto-mineral sorbents as an antiseptic and stimulating regeneration agent are presented. The effect of modified montmorillonite-containing clay with an extract of the medicinal plant Thymus serpylum on the healing process of purulent-necrotic lesions of the skin in laboratory Wistar rats was studied. In the course of the research, the wound-healing effect of phyto-mineral adsorbents in the form of powder and gel was studied. Panthenol Pharmstandard was used as a reference drug. The clinical picture of the blood of rats after the application of a model wound was also investigated, and data on platelet, leukocyte, and red blood cell studies are presented. where Panthenol Pharmstandard was used, was the lowest (on average, 65\% less than other groups). However, the use of phyto-mineral sorbents in the form of a powder stimulated a more earlier decrease in the area of the wound defect than in other animals. It was also proved that when using phytomineral sorbents in the early stages of the wound process, it contributes to the rapid restoration of connective tissue. Secondary reinfection did not occur, due to the high sorption capacity of drugs. blood of rats.

Keywords: phytomineral sorbent, septic wounds, hemosorbtion, morphological analysis of the

\section{Введение}

Раневой процесс занимает одно из ведущих мест среди хирургической заболеваемости. Возникающие в последствие гнойно-воспалительные процессы наблю- 
даются у 35-45\% хирургических больных [1]. Инфекция является причиной не только различных хирургических заболеваний, но и многочисленных послеоперационных осложнений: от нагноения послеоперационной раны до развития хирургического сепсиса, который часто приводит к смерти больного. Образование любой раны сопровождается последовательностью местных и общих реакций организма. Это приводит к нарушению функций сердечно-сосудистой системы, лихорадке, сбою обмена веществ [2].

На сегодняшний день представлен большой спектр методов лечения гнойных ран, в основном направленные на местное лечение. Однако, многие из препаратов в настоящее время во многом утратили свою клиническую значимость, что обусловлено эволюцией микроорганизмов и возрастанием их резистентности к определенным лекарствам [3].

\section{Эксперимент}

Фитоминералсорбент (далее ФМС) - это комплексный сорбционный композит, основанный на неорганических минералах группы монтмориллонита и экстракта лекарственного растения Thymus serpylum. Данное средство оказывает угнетающее действие на патогенную микрофлору $[4,5]$ и обладает антисептическими свойствами, которые стимулируют процессы регенерации [6,7]. Для удобства применения при аппликации ран ФМС использовали в двух формах: присыпка и гель [8].

Изучение влияния ФМС на процесс заживления гнойно-некротических поражений кожных покровов проводилось на белых крысах с исходной массой 180-200 г обоего пола. Для исследования применялись здоровые животные с чистыми кожными покровами, прошедшие карантин в течение 14 суток и после карантина были рандомизированы по полу и массе тела. Условия содержания во время проведения исследования: температура воздуха $-22 \pm 2^{\circ} \mathrm{C}$, влажность $40-70 \%$, световой режим 12 часов день, 12 часов ночь, по 6 крыс одного пола в клетке площадью $1600 \mathrm{~cm}^{2}$. 3а 1-2 дня до эксперимента кожу животных освобождали от шерсти с помощью крема для депиляции. Поверхность освобожденного от шерсти участка кожи составляла приблизительно $5 \times 5$ см, что составляет около $10 \%$ от общей поверхности тела животных.

Крысам были смоделированы гнойные раны. За 4 часа до операции отменялся прием корма и воды. Наркоз осуществлялся хлоралгидратом (300 мг/кг) и золетилом (150 мг/кг) внутрибрюшинно. Раны наносили в межлопаточной области средним диаметром 2.83 см, что составляло $1 \%$ от всей поверхности кожи животных. В область ранения, с помощью кисетного шва, вшивали специальный порт (для сбора экссудата и локального исследования раны), в него вносили определённое средство, соответствующее экспериментальным группам. Далее на область раны наносили штамм Escherichia coly в фиксированной заражающей дозе $2 \cdot 10^{8}$ микробных тел.

Перевязку с помощью ФМС (присыпка, гель) осуществляли путём наложения 0.1 г препарата на повреждённую область ежедневно в течении всего периода эксперимента один раз в сутки.

В ходе проведения исследовательской работы изучали ранозаживляющее действие ФМС в формах присыпки и геля. В качестве препарата сравнения использовали «Пантенол Фармстандарт»

Весь эксперимент проводили в течении 21 суток, что соответствует общепринятым срокам заживления раны [9-13]. Весь период ранозаживления был разделён на три этапа: воспаление, регенерация, образование рубца.

Круть и др. / Сорбционные и хроматографические процессы. 2018. Т. 18. № 6 


\section{Обсуждение результатов}

В ходе эксперимента было проведено планиметрическое исследование раневого дефекта кожи у лабораторных животных. Результаты исследования приведены на рисунке 1.

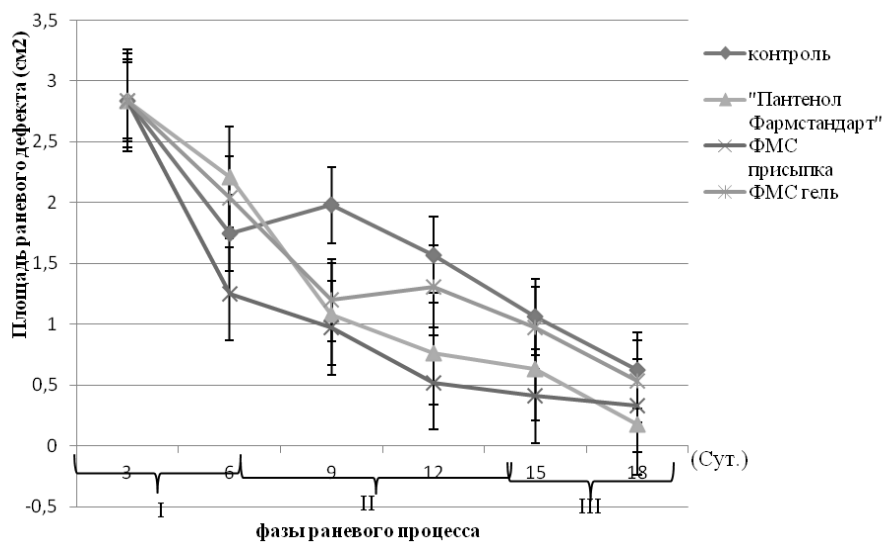

Рис. 1. Изменение площади раневого дефекта при моделировании гнойной раны у крыс в эксперименте

На 18 сутки в группе, где лечение ран производили гелевой формой ФМС, площадь раневой поверхности достоверно была меньше исходного значения на $81 \%$. Показатель площади раневой поверхности у животных, где использовали «Пантенол Фармстандарт», был самый низкий (в среднем на 65\% меньше относительно остальных групп). Однако, применение ФМС в форме присыпки стимулировало более ранее уменьшение площади раневого дефекта, нежели у остальных животных.

Защитные силы организма при травмах у животных зависят от функционального состояния клеточного и гуморального звеньев иммунной системы, соединительной ткани и многих других систем, работа которых направлена на борьбу с инфекцией раневого дефекта в тканях и интоксикацией [14].

На протяжении всего эксперимента нами изучались морфологические показатели периферической крови у животных опытных и контрольных групп.

Клиническая картина крови крыс после нанесения модельной раны показывает, что у всех экспериментальных животных наблюдались острые кровопотери и резкое угнетение функций образования новых клеток.

Концентрация эритроцитов в крови животных существенно была увеличена на 6 сутки после нанесения модельной раны, что указывает на переход из фазы воспаления в фазу пролиферации и очищение раны от продуктов распада (рис. 2)

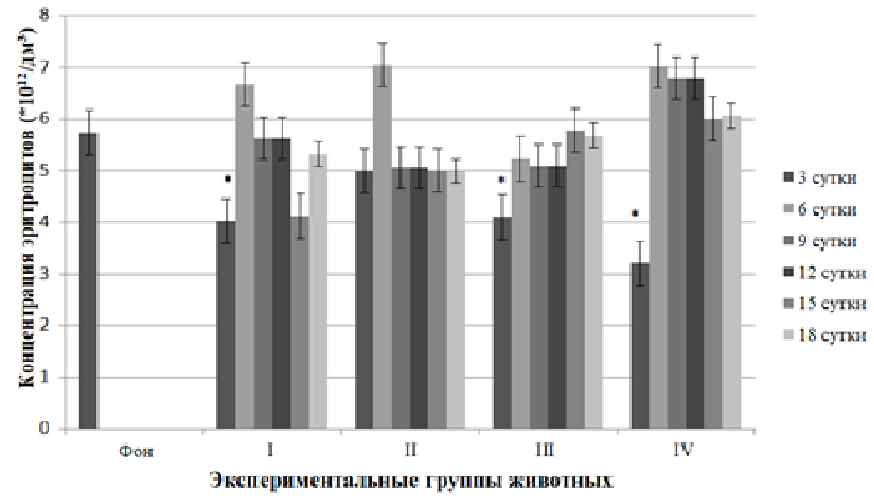

*достоверные отличия от соответствующих показателей у животных с фоновым показателем, $\mathrm{p}<0.5$

Рис. 2. Изменение концентрации эритроцитов при моделировании гнойной раны у крыс в эксперименте 
Адгезия тромбоцитов к эндотелию и субэндотелиальному матриксу является начальным этапом гемостаза и тромбоза. Количество тромбоцитов существенно было увеличено на 6 сутки после нанесения модельной раны, что указывает на высокое тромбообразование. В фазу регенерации уровень тромбоцитов постепенно снижается, таким образом, восстанавливается целостность эндотелия кровяного русла (рисунок 3).

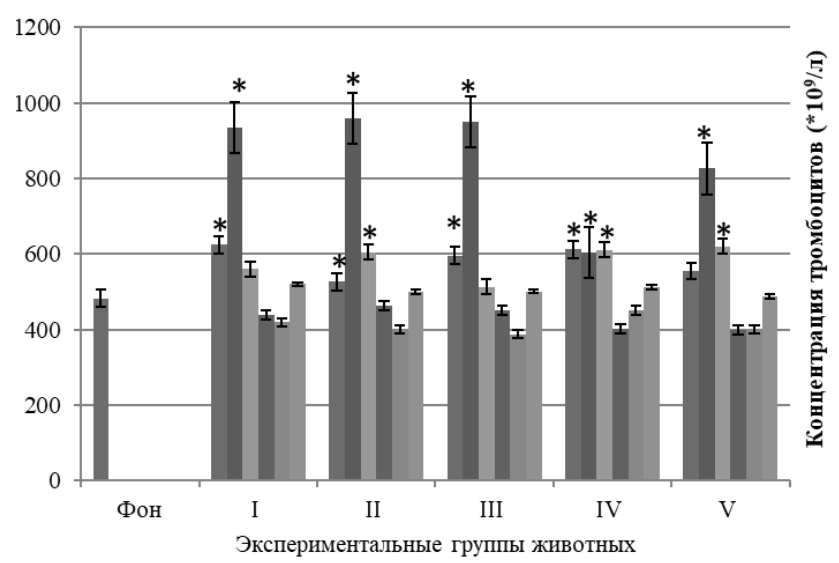

*достоверные отличия от соответствующих показателей у животных с фоновым показателем, $\mathrm{p}<0.5$

Рис. 3. Изменение концентрации тромбоцитов при моделировании гнойной

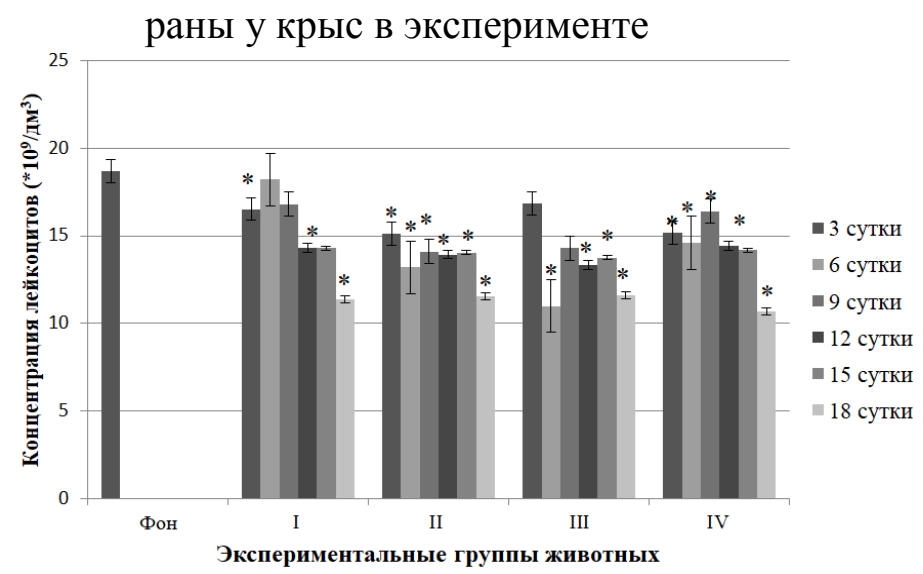

*достоверные отличия от соответствующих показателей у животных с фоновым показателем, $\mathrm{p}<0.5$

Рис. 4. Изменение концентрации лейкоцитов при моделировании гнойной раны у крыс в эксперименте

Концентрация лейкоцитов в крови у крыс была занижена. В III и V группах данный показатель достоверно ниже нормы на 19\% (рис. 4).

\section{Заключение}

Установлено, что наиболее выраженным влиянием на заживление гнойных ран обладает фитоминералосорбент на основе монтмориллонита в форме присыпки. Выживаемость животных при использовании фитоминералсорбентов составила более $65 \%$, в то время как в контрольной менее $35 \%$.

Содержание незрелых нейтрофилов в фазу регенерации у животных с применением ФМС в форме присыпки было ниже в 2 раза относительно контрольной группы и группы животных с применением препарата «Пантенол Фармстандарт».

Концентрация общего белка в группе крыс, где производили лечение ФМС на основе монтмориллонита в форме присыпки, была достоверно ниже контроля - на 
26\% в первые сутки после начала лечения, на 52\% - во вторые, на третьи сутки экссудация прекратилась.

\section{Список литературы}

1. Туйсин С.Р. // Фундаментальные исследования. 2010. № 1. С. 91-94.

2. Тулев Ю. // Молочное и мясное скотоводство. 2007. № 5. С. 30-31.

3. Токмакова А.Ю.,. Страхова Г.Ю, Галстян Г.Р. // Сахарный диабет. 2005. № 1. C. $42-48$.

4. Везенцев А.И., Трубицин М.А. // Сорбционные и хроматографические процессы. 2012. T. 12. № 6. C. 998-1004.

5. Везенцев А.И., Королькова С.В., Буханов В.Д // Научные ведомости БелГУ. Сер. Естественные науки. 2010. № 9 (80). С. 119-123.

6. Буханов В.Д., Везенцев А.И., Нгуен Хоай Тьяу и др. // Научные ведомости БелГУ. Сер. Медицина и фармация. 2014. № 11 (182). C. 181-186.

7. Жигжитжапова С.В., Рабжаева А.Н., Звонцов И.В. и др. // Химия растительного сырья. 2008. № 1. С. 73-76.

\section{References}

1. Cuisin S.R., Fundamental research, 2010, No 1, pp. 91-94.

2. Tulev Yu., Dairy and beef cattle, 2007, No 5, pp. 30-31.

3. Tokmakova A.Yu.,. Strakhova G.Yu, Galstyan G.R., Diabetes mellitus, 2005, No 1, pp. 42-48.

4. Vezentsev M.I., Trubitsin M.A., Sorbtsionnye $i$ khromatograficheskie protsessy, 2012, Vol. 12, No 6, pp. 998-1004.

5. Vezentsev A.I., Korolkova S.V., Bukhanov V.D., Bulletin of BSU. Ser. Natural science, 2010, No 9 (80), pp. 119-123.

6. Bukhanov B.D., Vezentsev A.I., Nguyen Hoai Chau et al., Scientific statement BSU. Ser. Medicine and pharmacy,2014, No 11 (182), pp.181-186.

7. Igitabo S.V., Rabzhaeva A.N., Zvontsov V.I. et al., Chemistry of vegetable raw materials, 2008, No 1, pp. 73-76.

8. Гарник Т.П., Фролов В.М., Романюк Б.П. и др. // Украӥнський медичний альманах. 2009. T. 12. № 5. C. 215-219.

9. Алексеева Н.Т.,. Никитюк Д.Б, Клочкова С.В. // Журнал анатомии и гистологии. 2015. T. 4. № 1. C. 26-37.

10.Алексеева. Н.Т. Дис. д-ра мед. наук : Оренбург. 2015. 41 с.

11.Магомедов А.P. // Вестник Оренбургского государственного университета. 2011. № 16 (135). С. 308-309.

12.Бежин А.И., Панкрушева Т.А., Затолокина М.А. и др. // Современные проблемы науки и образования. 2015. № 3. С. 272.

13.Привольнев В.В., Каракулина Е.В. // Болезни и возбудители. 2011. Т. 13. № 3. С. 214-222.

14. Гайдуль К. В. Крат. информ. пособие для практ. врачей // Науч. информ. центр ООО «АБЛОмед». Новосибирск. 2005. С. 32

8. Garnik T. P., Frolov V. M., Romaniuk B.P. et al., Ukrainian medical almanac, 2009, Vol. 12, No 5, pp. 215-219.

9. Alexeeva N.T., Nikityuk D.B., Klochkova S.V., J. of anatomy and histology, 2015, Vol. 4, No 1, pp. 26-37.

10. Alexeyev. N.T. Dis. Dr. med. Sciences: Orenburg, 2015, pp. 41.

11. Magomedov A.R., Bulletin of the Orenburg state University, 2011, No 16 (135), pp. 308-309.

12. Bezhin A.I., Pankrusheva T.A., Zatolokina M.A. et al., Modern problems of science and education, 2015, No. 3. Pp. 272.

13. Privolnov V.V., Karakulina E.V., Diseases and pathogens, 2011, Vol. 13, No 3, pp. 214222.

14. Gaidul K.V. Krat. inform. manual for practice. doctors // nauch. inform. center, LLC "Abiomed". - Novosibirsk, Russia [B. I.], 2005, $32 \mathrm{pp}$. 


\section{Круть Ульяна Александровна - заместитель директора по проектной и} профориентационной деятельности, кандидат биологических наук, Белгородский государственный национальный исследовательский университет, Белгород

Везенцев Александр Иванович - заведующий кафедрой общей химии института фармации, химии и биологии, д.т.н., професcop, Белгородский государственный национальный исследовательский университет, Белгород

Кузубова Елена Валерьевна - студент института фармации, химии и биологии, фармацевтический факультет, Белгородский государственный национальный исследовательский университет, Белгород

Радченко Александра Игоревна - студент института фармации, химии и биологии, фармацевтический факультет, Белгородский государственный национальный исследовательский университет, Белгород

Шайдорова Галина Михайловна магистрант института фармации, химии и биологии, химический факультет, Белгородский государственный национальный исследовательский университет, Белгород
Krut Uliana A. - deputy director for project and career guidance, candidate of biology, Belgorod National Research University, Belgorod. ulyanamontus@mail.ru

Vezentsev Alexandr I. - head of the department of general chemistry of the Institute of pharmacy, Doctor of engineering, professor, chemistry and biology, Belgorod National Research University, Belgorod. vesentzev@bsu.edu.ru

Kuzuvova Elena V. - student of the Institute of pharmacy, chemistry and biology, faculty of pharmacy, Belgorod National Research University, Belgorod.1015artek1015@mail.ru

Radchenko Alexandra I. - student of the Institute of pharmacy, chemistry and biology, faculty of pharmacy, Belgorod National Research University, Belgorod. sandrinkaradchenko@gmail.com

Shaydorova Galina M. - master degree (магистр) of the Institute of pharmacy, chemistry and biology, faculty of pharmacy, Belgorod National Research University, Belgorod. $\underline{800761 @ \text { bsu.edu.ru }}$ 